\title{
Measurement of $\mathrm{CO}_{2}, \mathrm{O}_{3}$ and VOC Levels and their Relationship to Educational Quality in Engineering Students at the National University of Chimborazo Unach During the COVID-19 Pandemic
}

\author{
Pérez Pirela Maribel Cecilia ${ }^{1}$ and Rodríguez Rodríguez Miguel Eduardo ${ }^{2}$ \\ ${ }^{1}$ Faculty of Engineering, National University of Chimborazo UNACH, Riobamba, C.P. 060150, Ecuador. \\ ORCID: 0000-0002-9687-5471, \\ ${ }^{2}$ Faculty of Humanistic and Technological Sciences, National University of Chimborazo UNACH, Riobamba, \\ C.P. 060150, Ecuador. ORCID: 0000-0001-8477-6612,
}

\begin{abstract}
This research aims to analyze the levels of $\mathrm{CO} 2, \mathrm{O} 3$ and $\mathrm{VOC}$ and their relationship with educational quality in engineering students at the National University of Chimborazo UNACH during the COVID-19 pandemic. The study had a quantitative, exploratory analysis design. The study had a quantitative, exploratory analysis design. Four environmental meteorological monitoring stations were used for data collection, to obtain contamination levels of VOC particles, temperature, winds, and precipitation. A questionnaire was also applied to 150 students of the UNACH, to determine the level of educational quality during the educational semester of COVID-19. The results were analyzed in a descriptive and comparative way with different sources and authors. Among the results it can be concluded that there was an almost total absence of chemical emissions by industries and vehicles in the city of Riobamba - Ecuador from March 2020 to July 2020. The covid-19 in no way has a positive side for the environment, nor for university education. The quality of education has been diminished by the lack of virtual academic training and lack of digital resources for students to receive educational training at a distance.
\end{abstract}

Keywords: University education, COVID-19, Air pollution, Riobamba, Research.

\section{INTRODUCTION}

Air pollution is currently one of the major environmental problems in urban areas around the world. In both developed and developing countries, there is a high volume and diversification of industrial production. There is also an intense flow of motor vehicles, which by their internal combustion design generate pollutants in nature [1].

In the case of air pollution, the main control measures adopted by the Ecuadorian environmental authorities have been oriented towards the control of particulate matter [2]. Volatile organic compounds (VOC) and compounds such as carbon dioxide $\left(\mathrm{CO}_{2}\right)$, sulfur dioxide $\left(\mathrm{SO}_{2}\right)$, among others, affect ozone $\left(\mathrm{O}_{3}\right)$, reaching the limits of destruction. However, the Ecuadorian authorities have seen the need to increase the stringency in the levels allowed for the emission of volatile organic compounds VOCs [3].

Ozone $\left(\mathrm{O}_{3}\right)$ is a triatomic molecule formed by oxygen atoms [4]. It is a much more reactive allotrope of oxygen than diatomic oxygen $\left(\mathrm{O}_{2}\right)$. It is a powerful oxidant that reacts rapidly with other chemical compounds, and is unstable when found in high concentrations [5]. Under normal atmospheric conditions, ozone decays to diatomic oxygen within approximately 30 minutes. In 1840, the German chemist Christian Friedrich Schönbein gave it the name ozone, from the Greek root ozein (smell), because of its characteristic smell [6].

Ozone is a natural component of the atmosphere that is found in low concentrations and is vital for life. Most of the ozone is found in the upper part of the atmosphere in a region of the stratosphere, more than $20 \mathrm{~km}$ from the surface, called the ozonosphere, where more than $90 \%$ of the atmospheric ozone is concentrated and forms a layer that limits the entry of ultraviolet radiation from the Sun [7].

The Constitution states that the State shall protect the right of the population to live in a healthy and ecologically balanced environment that guarantees sustainable development [8]. The Republic of Ecuador will ensure that this right is not affected and will guarantee the preservation of nature. In Ecuador, air pollution is caused by deficiencies in some aspects related to territorial planning of human settlements, industries, the use of obsolete technologies in production and transportation activities, poor fuel quality, and open-pit mining, among others [9].

According to official studies published by SENPLADES in 2017, the country's air quality management presents problems such as: lack of follow-up to signed agreements, legislative dispersion, dispersion of jurisdiction and competencies, and institutional and budgetary weakness of the MAE [10].

Additionally, the different entities involved in environmental air management maintain dispersed, scarce and unconfined information. Only in the city of Quito, through the Air Review Corporation (CORPAIRE), does it maintain systematic, verified and controlled information on vehicle emissions and air quality. The problem increases if we take into account that, in addition to Quito, only Guayaquil and Cuenca have involved 
International Journal of Engineering Research and Technology. ISSN 0974-3154, Volume 13, Number 8 (2020), pp. 2007-2013

(C) International Research Publication House. https://dx.doi.org/10.37624/IJERT/13.8.2020.2007-2013

the air component in their municipal environmental development plans and that Ecuador has 16 population centers with more than 100,000 habitants.

Since July 2019, in the city of Riobamba the National University of Chimborazo UNACH, applies the Project for monitoring and measuring levels of $\mathrm{CO}_{2}-\mathrm{O}_{3}-$ VOC. This Project analyzes the relationship between indoor air quality at the National University of Chimborazo of the Engineering Faculty. Since March 14, 2020 the Republic of Ecuador, decreed a state of quarantine for the COVID-19 pandemic.

COVID-19 is a new form of Coronavirus disease which is due to the new SARS-CoV2 virus. COVID-19 causes an acute infection with respiratory symptoms. This new virus is different from those that cause SARS (Severe Acute Respiratory Syndrome) or MERS (Middle Eastern Respiratory Syndrome) [11]. Coronaviruses are a large family of viruses, some of which have the ability to be transmitted from animals to humans. They produce clinical manifestations ranging from the common cold to more serious illnesses, such as the coronavirus that caused SARS-CoV and the coronavirus that caused MERS-CoV.

The number of cases has increased rapidly, and the World Health Organization (WHO) has already considered COVID19 a pandemic. This means that the virus is spreading simultaneously in more than three different geographical regions of the world. Both in Ecuador and in many countries, the global pandemic is affecting all aspects of world welfare.

Prior to COVID-19, Ecuador shows low growth, limited fiscal policy space and increasing social conflicts. The country's structural paralysis is generating the largest recession the region has ever suffered. At the educational level, students must adapt to an exclusive online educational model. In this way, engineering students experience great changes in their educational status. Likewise, air quality presents distinguishable changes.

These climatic and educational changes that are presented by the levels of VOC, due to the COVID-19 pandemic will be described and analyzed in the present study that aims to describe the levels of $\mathrm{CO}_{2}, \mathrm{O}_{3}$ and VOC to verify their relationship with the educational quality in the engineering students of the National University of Chimborazo during the Covid-19 pandemic.

\section{MATERIALS AND METHODS}

At a methodological level, the study was formalized in the quantitative paradigm. The research focused on scalar quantitative results from different sources or data collection instruments. These were contrasted to establish a level of relationship through the method of traingulation [12]. Four monitoring stations were established in the city of Riobamba. These environments, which are typical and characteristic of different parts of the city, made it possible to obtain and measure data representing areas with similar characteristics. Another aspect to consider was meteorology, especially wind direction and speed, temperature and average precipitation levels, which influenced the distribution and dispersion of
VOCs during the period July-2019 July-2020.

Four environmental monitoring stations (SVT-EMA) were used as data collection instruments at the meteorological points to check wind speed and VOC levels. Particle collection measurements were established in micrograms per cubic meter $\left(\mu \mathrm{g} / \mathrm{m}^{3}\right)$.

According to [13], PM is divided into two standard measurements. The first measure is $\mathrm{PM}_{2.5}$ with a weight of 10 $\mu \mathrm{g} / \mathrm{m}^{3}$ for an annual mean and $25 \mu \mathrm{g} / \mathrm{m}^{3}$ for a 24 -hour mean. The second measure is $\mathrm{MP}_{10}$ with a weight of $20 \mu \mathrm{g} / \mathrm{m}^{3}$ as an annual average and $50 \mu \mathrm{g} / \mathrm{m}^{3}$ as a 24-hour average. The Republic of Ecuador is a developing country, therefore the $\mathrm{PM}_{2.5} / \mathrm{MP}_{10}$ ratio is applied for a total of 0.5 . Based on known health effects, guidelines are needed for both short (24-hour) and long (annual average) exposure for the two indicators of $\mathrm{PM}$ contamination. As a guideline value for $\mathrm{PM}_{2.5}$ in long-term exposures, the annual mean concentration of $10 \mu \mathrm{g} / \mathrm{m}^{3}$ recommended by [13] was chosen.

From July 2019 to July 2020 the 4 SVT-EMA units were named Mon1, Mon2, Mon3 and Mon4. A total of 12 samples were obtained (an average sample of the 4 stations for each month). The levels of $\mathrm{CO}_{2}$ (Carbon Dioxide) and $\mathrm{O}_{3}$ (Ozone) were analyzed. As VOC, the average value of Nitrogen Oxides (NO and NO2) and Sulfur Dioxide (SO2) particles collected on average during one year was considered.

At the same time, a digital questionnaire via email was applied to 150 students of the Faculty of Engineering of the UNACH. The questions were related to the current educational model and air pollution, with the variable educational quality. The answer options were, Always (A) as the first option with a score of 5, the second option, almost always (AA) with 4 points, the third option Some Times (S) with three points. The fourth option Almost Never (HE) with two points. The fifth option was Never (N) with the lowest score of 1 point (see table 1).

Table 1. Questionnaire applied to the students of the Faculty of Engineering of the UNACH

\begin{tabular}{|l|l|l|l|l|l|}
\hline \multirow{2}{*}{ Ítems } & \multicolumn{3}{|l|}{ Options } \\
\cline { 2 - 6 } & A & AA & S & HE & N \\
\hline $\begin{array}{l}\text { You think air pollution } \\
\text { affects college students }\end{array}$ & & & & & \\
\hline $\begin{array}{l}\text { Can face-to-face engineering } \\
\text { classes be replaced by virtual } \\
\text { activities? }\end{array}$ & & & & & \\
\hline $\begin{array}{l}\text { Does nature have any positive } \\
\text { benefit from quarantine } \\
\text { months? }\end{array}$ & & & & & \\
\hline
\end{tabular}

The results obtained were analyzed descriptively by the researchers. Written sources were triangulated in a descriptive way to establish the suitable and unsuitable levels of VOCs in the environment, in order to establish the effects of educational quality during the national quarantine stage of the COVID-19. The results are presented in the following chapter. 
International Journal of Engineering Research and Technology. ISSN 0974-3154, Volume 13, Number 8 (2020), pp. 2007-2013

(C) International Research Publication House. https://dx.doi.org/10.37624/IJERT/13.8.2020.2007-2013

\section{ANALYSIS AND DISCUSSION OF RESULTS}

The four SVT-EMA weather data collection units called Mon1, Mon2, Mon3 and Mon4 were located in the city of Riobamba, Ecuador (see figure1).

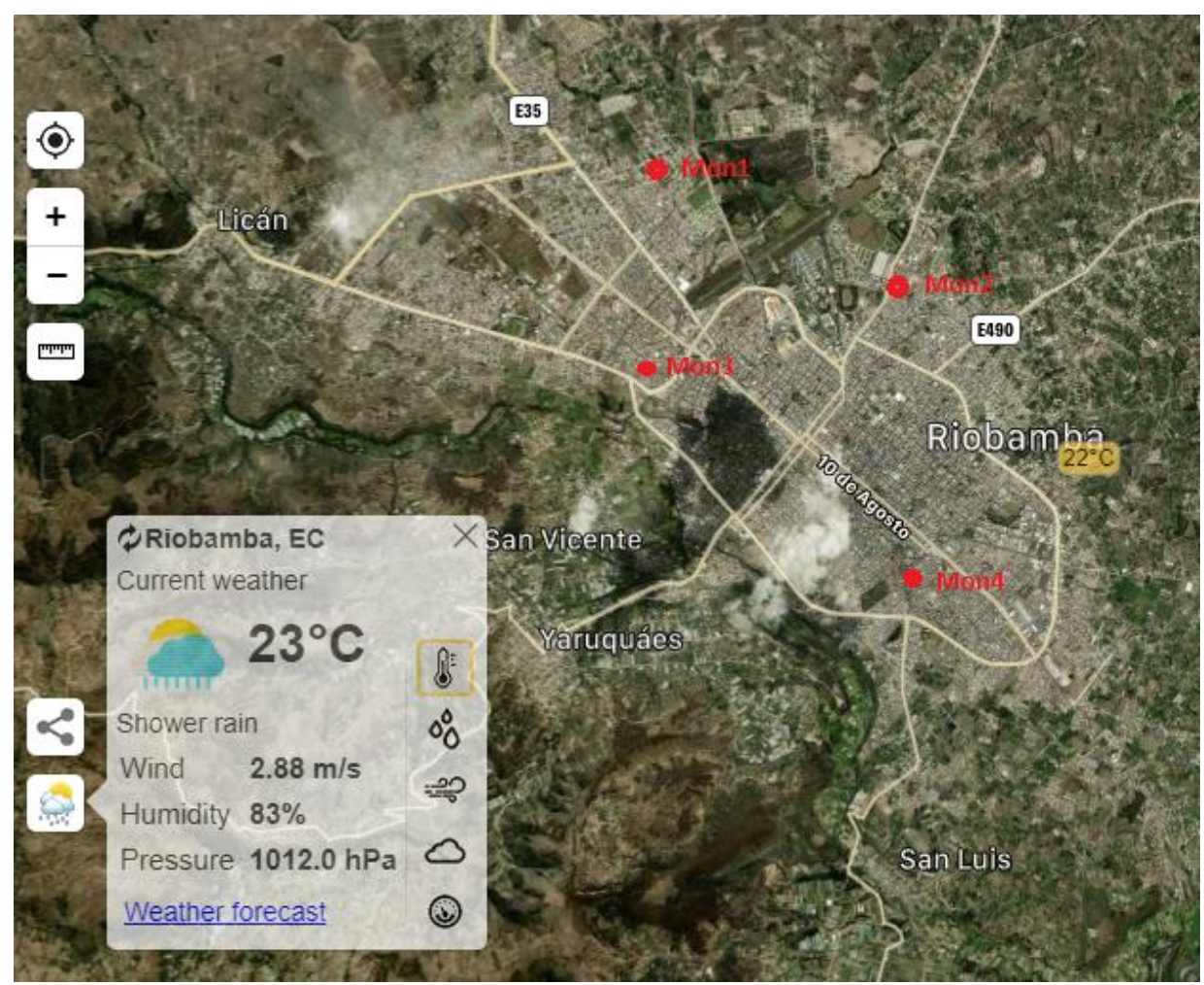

Figure 1. Location of weather monitoring points (Mon1, Mon2, Mon3 and Mon4) in the city of Riobamba, Ecuador

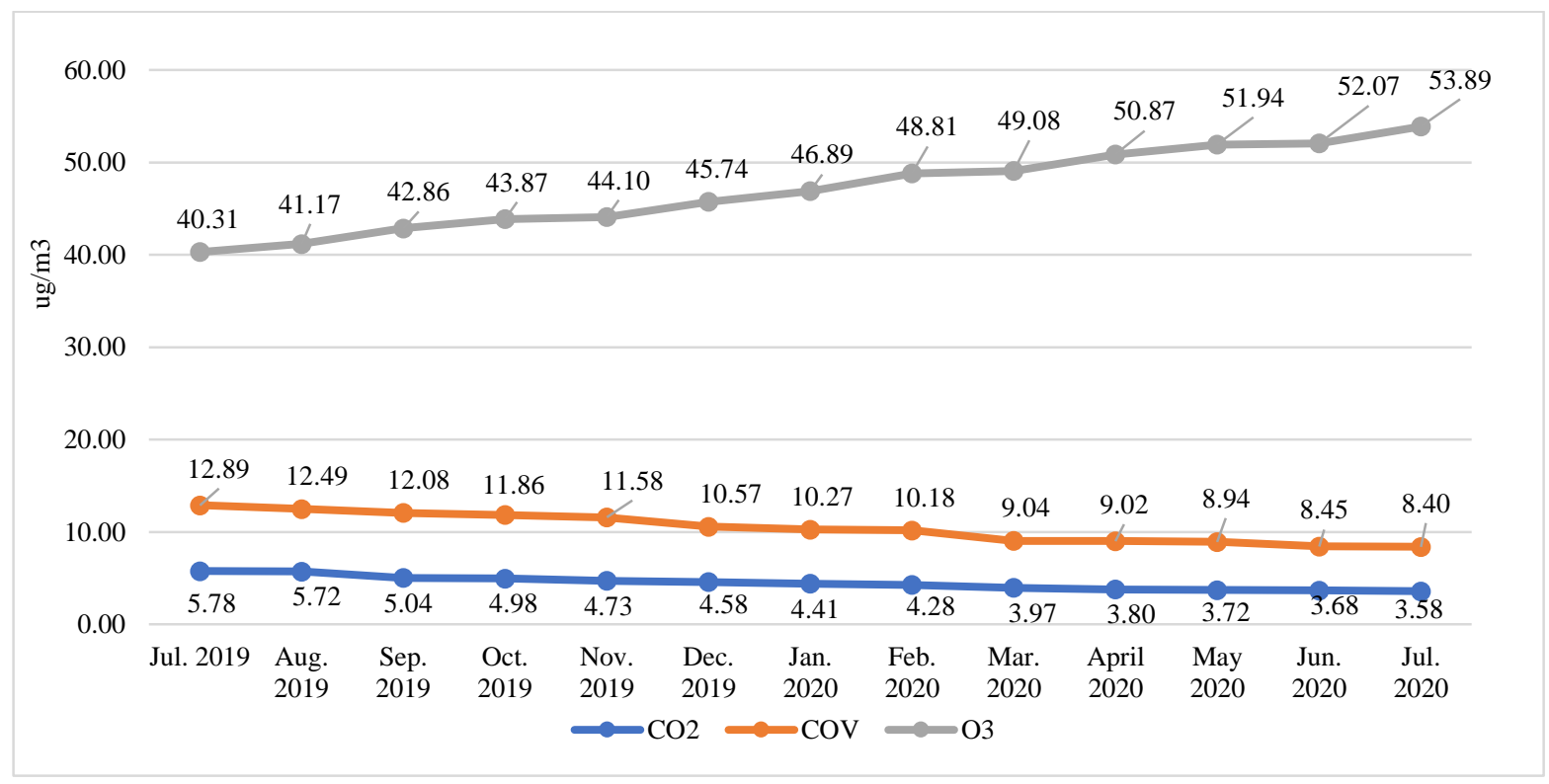

Figure 2. Representation of $\mathrm{CO}_{2}, \mathrm{O}_{3}$ and VOC levels from July 2019 to July 2020.

The averages of $\mathrm{CO}_{2}$ Particulate Matter (PM) were decreasing or declining, from July 2020 with a high value of $12.89 \mu \mathrm{g} / \mathrm{m}^{3}$ to the level of $8.40 \mu \mathrm{g} / \mathrm{m}^{3}$. Also the average VOC levels were decreasing with a value of $5.78 \mu \mathrm{g} / \mathrm{m}^{3}$ in July 2019, to a minimum value in July 2020 with a value of $3.58 \mu \mathrm{g} / \mathrm{m}^{3}$. On the contrary, the $\mathrm{O}_{3}$ levels showed an increase. The $\mathrm{O}_{3}$ values in July 2019 were $40.31 \mu \mathrm{g} / \mathrm{m}^{3}$, an increase to $53.89 \mu \mathrm{g} / \mathrm{m}^{3}$ in July 2020. 
International Journal of Engineering Research and Technology. ISSN 0974-3154, Volume 13, Number 8 (2020), pp. 2007-2013

(C) International Research Publication House. https://dx.doi.org/10.37624/IJERT/13.8.2020.2007-2013

For [14] the maximum average VOC levels are $100 \mu \mathrm{g} / \mathrm{m}^{3}$ in $8 \mathrm{~h}$, which is also a recommended limit in the Guidelines of [13]. The results show that the levels are lower than the maximum measurements of VOCs, $\mathrm{O}_{3}$ and $\mathrm{CO}_{2}$, but effective results are demonstrated in terms of PM.

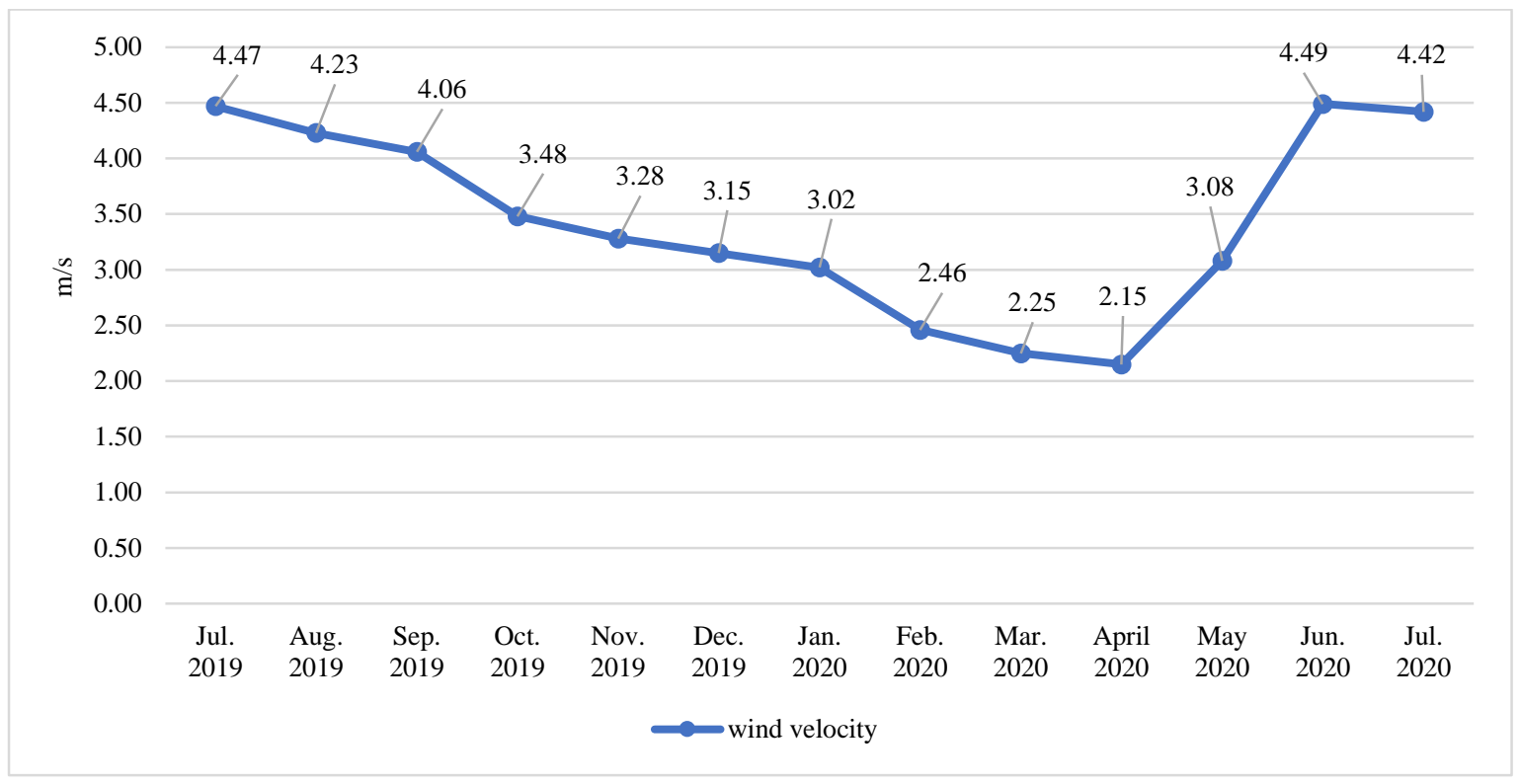

Figure 3. Average monthly wind measurements from July 2019 to July 2020 in the city of Riobamba - Ecuador.

Maximum value of wind speed was in the month of June 2020 with $4.49 \mathrm{~m} / \mathrm{s}$. The minimum value in the month of April 2020 with $2.15 \mathrm{~m} / \mathrm{s}$. From July 2019 with a measurement of $4.47 \mathrm{~m} / \mathrm{s}$ there was a continuous decrease until April 2020. The predominant wind direction during all months from July 2019 to July 2020 was towards the southeast (28\%), with an average speed of $3.71 \mathrm{~m} / \mathrm{s}$.

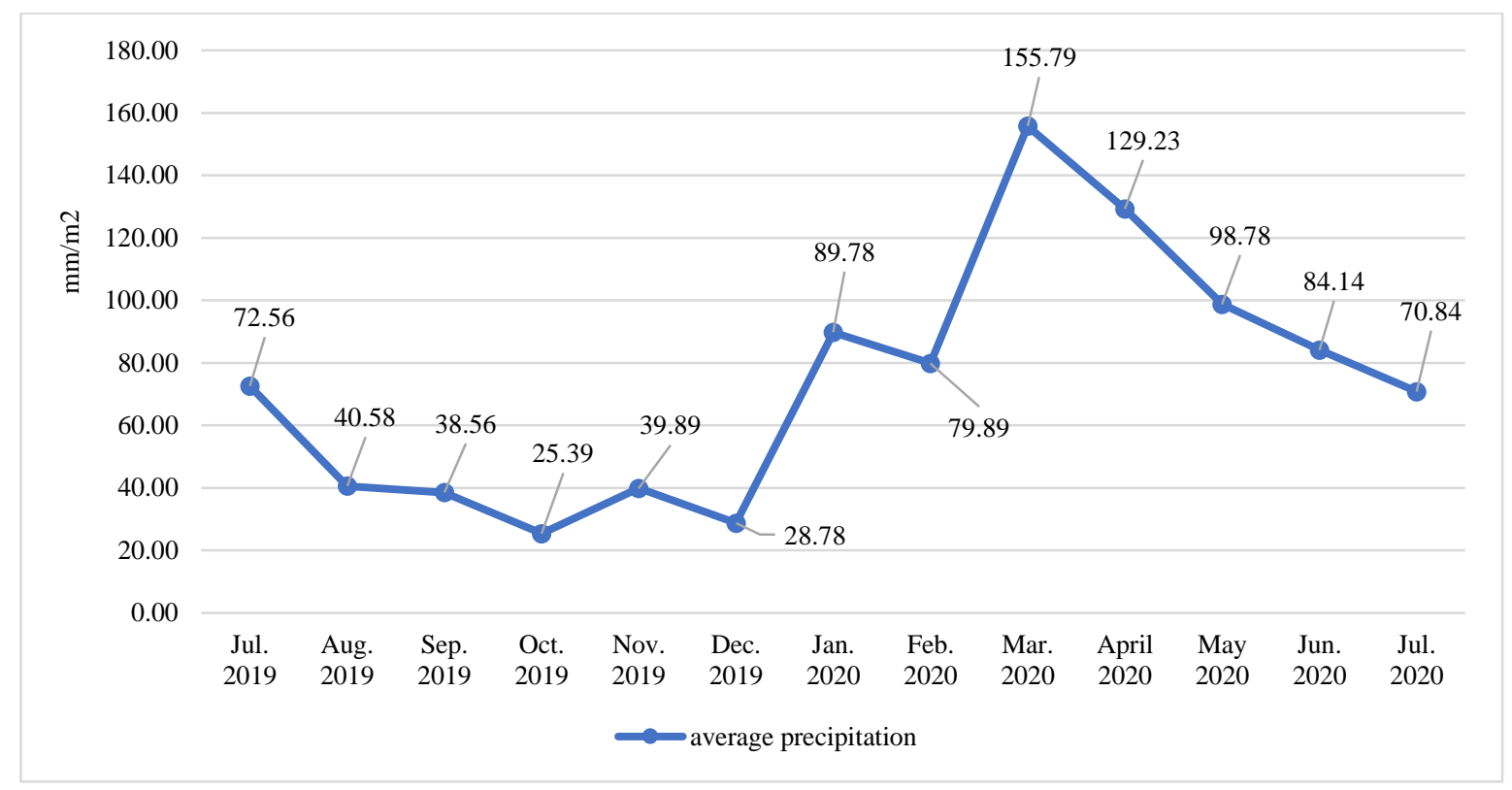

Figure 4. Average monthly rainfall from July 2019 to July 2020 in the city of Riobamba.

From December with a level of $28.78 \mathrm{~mm} / \mathrm{m}^{2}$ the rainy season starts. The rains culminate until March with a level of 155.79 $\mathrm{mm} / \mathrm{m}^{2}$ 
International Journal of Engineering Research and Technology. ISSN 0974-3154, Volume 13, Number 8 (2020), pp. 2007-2013

(C) International Research Publication House. https://dx.doi.org/10.37624/IJERT/13.8.2020.2007-2013

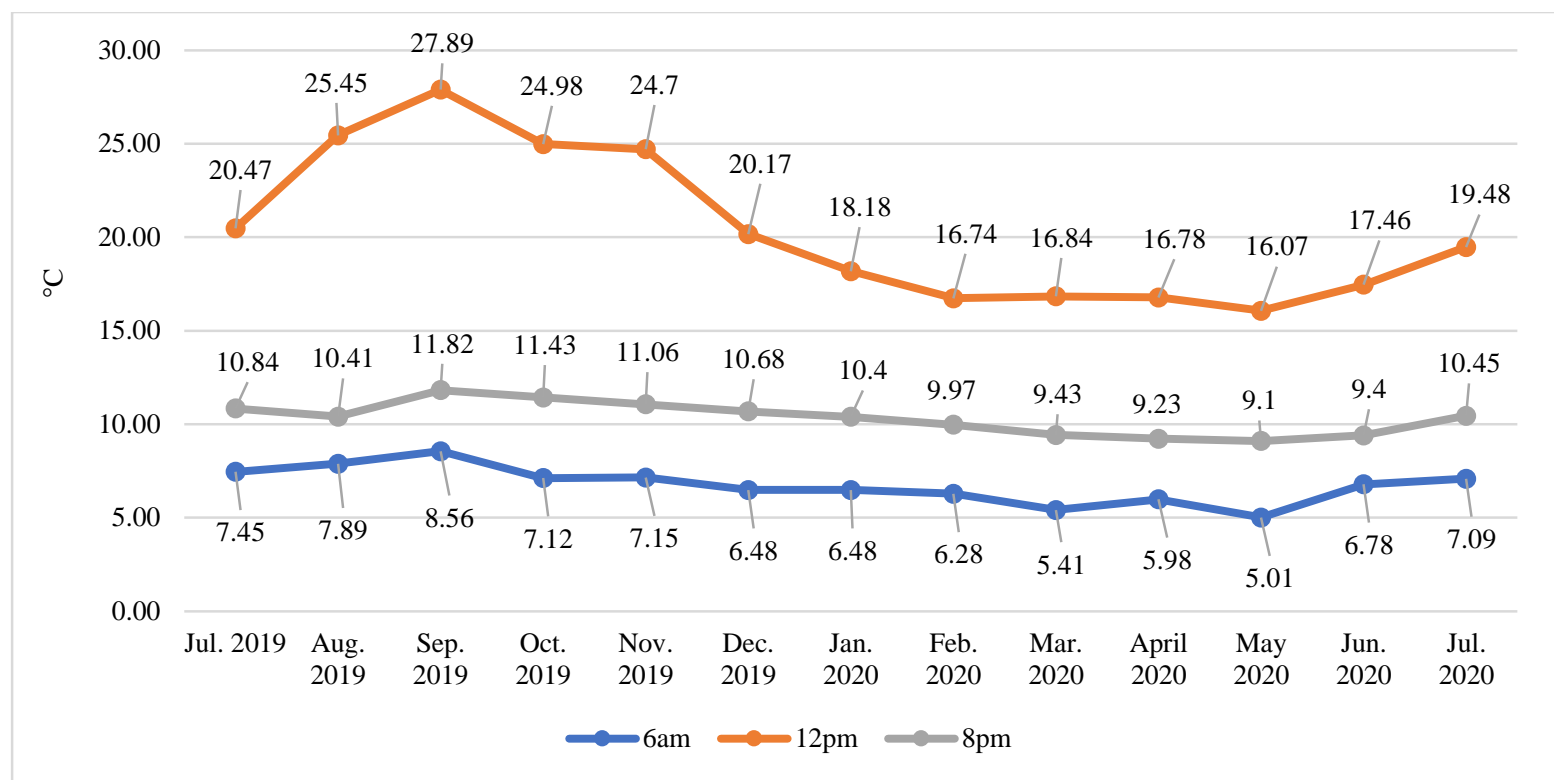

Figure 5. Average monthly temperature from July 2019 to July 2020 in the city of Riobamba - Ecuador.

Due to the variability of the temperature that can exist by the hour in a day, three measurements of temperature were considered. One measurement at $6 \mathrm{am}$, one measurement at $12 \mathrm{pm}$ and one measurement at $8 \mathrm{pm}$. The highest temperature levels were in September 2019 with $27.89^{\circ} \mathrm{C}$ at $12 \mathrm{pm}, 11.82^{\circ} \mathrm{C}$ at $8 \mathrm{pm}$ and $8.56^{\circ} \mathrm{C}$ at $6 \mathrm{am}$.

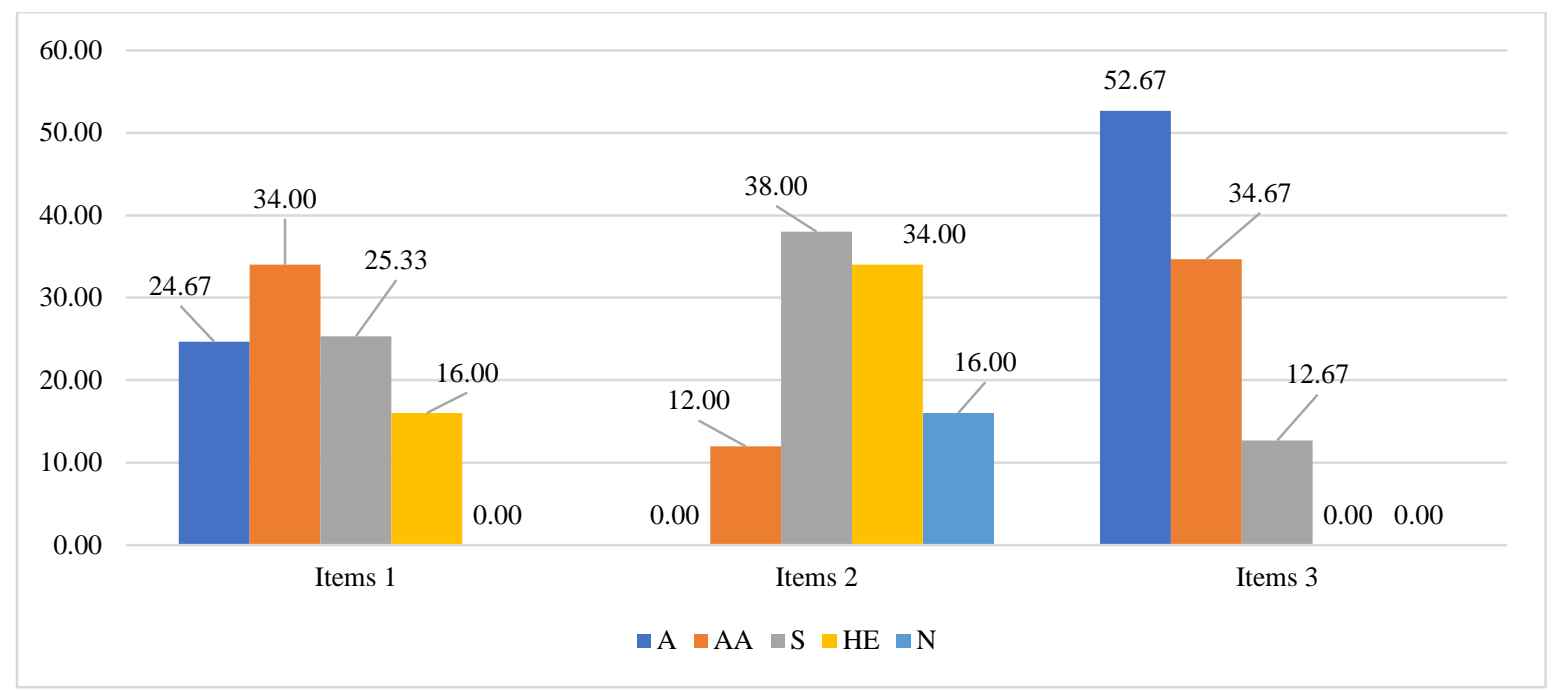

Figure 6. Results of the questionnaire applied to the students of the faculty of engineering of the National University of Chimborazo UNACH.

Item number 1 that expresses, "Do you consider that air pollution affects university students", was obtained as an answer that $34 \%$ of the surveyed students stated almost always, then $25.33 \%$ of the students stated sometimes. $24.67 \%$ of those surveyed always said, then $16 \%$ expressed almost never feeling affected by air pollution.

In item 2, Can face-to-face engineering classes be replaced by virtual activities? It was shown that most of them can sometimes be replaced by $38 \%$ of the participants. Then $34 \%$ said it was almost never. Then $16 \%$ never expressed and finally $12 \%$ highlighted that it can almost always be replaced by the face-to-face educational model.

The third item: Does nature have any positive benefits from the quarantine months? The majority of students, with $52.67 \%$, said that quarantine always has positive effects on nature. This is followed by $34.67 \%$ who say that it almost always and $12.67 \%$ sometimes. 
International Journal of Engineering Research and Technology. ISSN 0974-3154, Volume 13, Number 8 (2020), pp. 2007-2013

(C) International Research Publication House. https://dx.doi.org/10.37624/IJERT/13.8.2020.2007-2013

According to the students in their results, they show and consider that the polluting effects of the air affect their studies. By having respiratory symptoms these diminish the levels of concentration and relative studies in the university. For [15] the importance of the development of physical condition and ultimately air conditions, is focused primarily on improving health and self-knowledge of their possibilities and limitations, ie, we must incorporate the students enough knowledge to develop, with maximum autonomy, physical activity appropriate to their abilities and personal needs, allowing you to maintain an optimal quality of life.

According to researchers, the quality of engineering education is affected by the implementation of significant changes in the current educational model. Since the beginning of the pandemic, the government of the Republic of Ecuador requested to apply studies in a face-to-face modality. For [16] the virtual modality presents quality and effective results in theoretical subjects and careers, but in science and experimental careers such as mathematics or engineering, quality decreases due to the lack of guidance and monitoring of students.

Ground-level ozone - not to be confused with the ozone layer in the upper atmosphere - is one of the main components of smog. It is formed by the reaction with sunlight (photochemical) of pollutants such as nitrogen oxides (NOx) from vehicle emissions or industry and volatile organic compounds (VOCs) emitted by vehicles, solvents and industry. The highest ozone levels are recorded during periods of sunny weather.

Excess $\mathrm{O}_{3}$ has serious health effects. Excess ozone in the air can have significant adverse effects on human health. It can cause breathing problems, cause asthma, reduce lung function and lead to lung diseases.

According to [17] the relationship between PM exposure and adverse health effects has been documented in several studies, although only a few have investigated the impact of smoke on the health of students with acute bronchial asthma attacks. Cases of respiratory disease accumulate in cities with higher population concentrations. Among the main pollutants with the capacity to affect the health of individuals are those that come from primary emissions or atmospheric transformations. Motor vehicles are the most important source of some of these pollutants (particularly carbon monoxide), nitrogen oxides, unburned hydrocarbons, ozone and other photochemical oxidants, lead and, to a lesser extent, total suspended particles of sulfur dioxide and volatile organic compounds [18].

The student population is affected by polluting and stable emissions into the environment. The substances in vehicle emissions can cause irritating inflammatory effects on the respiratory system, the main ones being nitrogen, ozone, photochemical oxidants, sulfur dioxide and particulates [19]. Studies conducted in Riobamba, Ecuador, showed that the average annual concentration of total particles was significantly associated with the prevalence of coughing and bronchitis in school and university students, and was stronger in students diagnosed with asthma [19 and 20].

\section{CONCLUSIONS}

After having applied the final analyses of the results it can be concluded that covid-19 has in no way a positive side for the environment. Because the visible positive impacts such as the reduction of $\mathrm{Co} 2$ and VOCs, whether it be improved air quality or reduced greenhouse gas emissions, are only temporary, they are due to the tragic economic slowdown and human suffering. The almost total absence of chemical emissions by industries and vehicles in the city of Riobamba - Ecuador.

A decision must now be made whether to rescue polluting companies and use that rescue as leverage to impose reforms with an environmental focus, or to let them return to carbonintensive use as a measure to fix the economy quickly. At the educational level, the quality of education is radically reduced. Due to the lack of virtual culture in distance learning classes, also due to the negative effects that the population can acquire when exposed to Covid-19.

The respite that the planet is experiencing is temporary, he warns [21], to achieve a significant reduction in the amount of $\mathrm{CO} 2$ in the atmosphere, a sustained reduction of $10 \%$ globally in the use of fossil fuels should be achieved for one year, according to [22].

\section{RECOMMENDATIONS}

- Environmental pollution is the main problem in today's societies and will remain so until there is a radical change in development patterns.

- As long as excessive consumerism activities and the misuse of natural resources prevail, environmental conditions and the impact on the quality of life of human beings will continuously increase.

- Universities, as actors with social, educational, cognitive and organizational impact, must be active in their policies and plans in favor of sustainable development.

- They must include within their organizational values, the awareness to as future professionals seek to minimize the impacts of human activities on the environment and ensure the preservation of limited natural resources.

- It is recommended that virtual education be formalized in distance courses or seminars.

- Carry out research in controlled environments in the laboratory that simulate the conditions of climate and vegetation, to know the concentrations of pollutants (ozone, sulfur dioxide, nitrogen dioxide, and sedimentable particulate matter) that could affect air quality in the city of Riobamba

- It is recommended that a projection model be made to determine the concentration of the pollutants, due to the constant increase in vehicle traffic over a period of 10 to 15 years. 
International Journal of Engineering Research and Technology. ISSN 0974-3154, Volume 13, Number 8 (2020), pp. 2007-2013

(C) International Research Publication House. https://dx.doi.org/10.37624/IJERT/13.8.2020.2007-2013

\section{REFERENCES}

[1] R. Christopher Spicer, 2020, “Assessing background particulate contamination in an historic building - surface lead loading and contamination", Journal of the Air \& Waste Management Association, 70(8), pp. 745-752, DOI: $10.1080 / 10962247.2020 .1768966$

[2] Rodríguez-Guerra, A. \& Cuvi, N., 2019, “Article Contaminación del Aire y Justicia Ambiental en Quito, Ecuador". Fronteiras Journal of Social Technological and Environmental Science, 8(3), pp. 13-46. DOI: 10.21664/2238-8869.2019v8i3.p13-46

[3] Mario García G., Hermes Ramírez S., Héctor Ulloa G., Omar García G., Ángel Meulenert P., \& Jaime Alcalá G., 2013, "Concentration of pollutants $\mathrm{SO}_{2}, \mathrm{NO}_{2}$ and correlation with $\mathrm{H}+, \mathrm{SO}_{4}-2$ and $\mathrm{NO}_{3}$ - During wet season in the Metropolitan Zone of Guadalajara, Jalisco, Mexico". Rev Chil Enf Respir; 29, pp. 81-88.

[4] Esfandian, H., Esfandian, N., Rezazadeh, M., 2020, "Modeling and Comparison of Optimized Isotherm Models for $\mathrm{H}_{2}, \mathrm{~N}_{2}, \mathrm{CO}, \mathrm{CH}_{4}$ and $\mathrm{CO}_{2}$ Adsorption Using Cuckoo Search Optimization Algorithm". International Journal of Engineering, 33(5), pp. 712-719. DOI: 10.5829/ije.2020.33.05b.01

[5] Pretell Vasquez, C., Marquez Villacorta, L., \& Siche, R., 2016, "Effect of gaseous ozone on physicochemical characteristics, microbiological and general appearance of fresh wonderful Punica granatum L"., Scientia Agropecuaria, 7(3), pp. 173-180. DOI: 10.17268/sci.agropecu.2016.03.03

[6] Mordecai B., 2001, "The history of ozone. The schönbein period, 1839-1868”. Bull. Hist. Chem., 26(1), pp. 40-56.

[7] Kelly, V., Patiño, S., Arroyave, M. \& Marín, J., 2012, "Electrochemical Oxidation and Ozonation Applied to the Treatment of Wastewaters from Biodiesel Production”. Información Tecnológica, 23(2), pp. 41-52. DOI: $10.4067 / \mathrm{S} 0718-07642012000200006$

[8] Ministerio del Ambiente República del Ecuador, Plan nacional de la calidad del aire. Quito, 2010. Available at: https://www.ambiente.gob.ec/wpcontent/uploads/downloads/2012/10/libro-calidad-aire1-final.pdf

[9] Cadena F., F. Quiroz, I. Chango, P. Cazco, P. Recalde, M. Salinas \& Narváez, B., 2006, "La influencia de la atmósfera sobre el deterioro de los materiales metálicos. Presentación en láminas". Memorias del Primer Congreso Ecuatoriano sobre Gestión de la Calidad del Aire. Corporación para el Mejoramiento del Aire de Quito, Ecuador.

[10] República del Ecuador consejo nacional de planificación (CNP). Plan Nacional de Desarrollo 2017-2021-Toda una Vida. Available at https://www.planificacion.gob.ec/wpcontent/uploads/downloads/2017/10/PNBV-26-OCT-

FINAL_0K.compressed1.pdf

[11] American Thoracic Society, 2020, “QQué es el COVID19?”, ATS Patient Education Series 2020 American Thoracic Society, Online version updated April 28, 2020.
Available at https://www.thoracic.org/patients/patientresources/resources/spanish/covid-19.pdf

[12] Mendoza, D., La Madriz, J., López, M., y Ramón, V., 2018, "Research Competencies of Higher-Education Teaching Staff Based on Emotional Intelligence". Mediterranean Journal Of Social Sciences, 9(5), 131-144. DOI: $10.2478 / \mathrm{mjss}-2018-0137$

[13] WHO/SDE/PHE/OEH/06.02, 2005, “Guías de calidad del aire de la OMS relativas al material particulado, el ozono, el dióxido de nitrógeno y el dióxido de azufre. Actualización mundial 2005". Available at: https://www.who.int/phe/health_topics/AQG_spanish.pd f

[14] Banhazi, T., Aland, T. \& Hartung, J., 2018, “Air Quality and Livestock Farming. London, CRC Press.

[15] Iñaki Rabadán C. \& Rodríguez Barrios A., 2010, “La respiración y la relajación dentro de la educación secundaria: una aproximación conceptual a través de la revisión del temario para oposiciones". Revista Digital Buenos Aires, 15(146), pp. 1-2.

[16] Martínez, V., 2017, "Educación presencial versus educación a distancia”. La Cuestión Universitaria, 9, pp. 108-116.

[17] Samet, J. \& Krewski, D., 2007, "Health Effects Associated With Exposure to Ambient Air Pollution", Journal of Toxicology and Environmental Health, A(70), pp. 227-242. DOI: 10.1080/15287390600884644

[18] Lester, B. \& Seskin, E., 2013, “Air Pollution and Human Health”, New York, RFF Press.

[19] Bhola, R., Gurjar, L., Molina, T. \& Ojha, P. 2010, “Air Pollution: Health and Environmental Impacts". Boca Raton, CRC Press.

[20] Guamán-Gutiérrez Diana Soraya; Real-Cotto Jhony Joe; Alvarado-Franco Hugo Javier; Quinto-Briones Rina Mariuxi; Idrovo-Castro Katherine Janela; JaramilloFeijoo Leyda Elizabeth., 2019, "Chronic respiratory diseases and their relationship with spirometric patterns". INSPILIP, $3(1), \quad$ pp. $1-6 . \quad$ DOI: 10.31790/inspilip.v3i1.76.g146

[21] Cole. M., Ozgen, C. \& Strobl, E., 2020, “Air Pollution Exposure and COVID-19". IZA - Institute of Labor Economics, 13367, pp. 1-31.

[22] Zalakeviciute, R., Vasquez, R., Bayas, D., Buenano, A., Mejia, D., Zegarra, R., Diaz, A. \& Lamb, B., 2020, "Drastic Improvements in Air Quality in Ecuador during the COVID-19 Outbreak". Aerosol Air Qual. Res., 20, pp. 1783-1792. DOI: https://doi.org/10.4209/aaqr.2020.05.0254 